\title{
ANALISIS TINGKAT KEKUMUHAN PADA LOKASI PERMUKIMAN DI PERKOTAAN \\ (Studi Kasus : Kampung Rawa Badung, Kecamatan Cakung, Kota Jakarta Timur)
}

\author{
Marselly Dwiputri ${ }^{1}$, Nurjannah Hamdani ${ }^{2}$, Bambang Perkasa Alam ${ }^{3}$ \\ ${ }^{1}$ Universitas Indraprasta PGRI, Program Studi Arsitektur \\ marsellydwiputri@yahoo.com \\ ${ }^{2}$ Universitas Indraprasta PGRI, Program Studi Arsitektur \\ nurjannah.hamdani@gmail.com \\ ${ }^{3}$ Universitas Indraprasta PGRI, Program Studi Arsitektur \\ perkasaalam.bambang@gmail.com
}

\begin{abstract}
The emergence of slum in urban areas is a phenomenon that occurs in big cities in Indonesia, the conditions that occur in the city village is currently facing various problems, especially the quality and quantity in the environment Settlements related to the conditions of the facilities, infrastructure, and conditions of the building in the residential area. Kampung Rawa Badung is one of the residential areas that not only have the growing population growth and high population density, but also has the condition of the facility and infrastructure that is not adequate so Indications are slum due to affected environmental factors, especially the environment of residence. Therefore, the use of the scoring method in this research in the identification of slum area, which is then classified by four levels of the slums is not slum, mild slums, temperate slum and Heavy slum. Of the seven indicators of slums, Kampung Rawa Badung is in the category of medium with land legality, and the results of SWOT analysis as a reference to the slum handling solution in Kampung Rawa Badung and as a determination of priority handling in the region Settlements.
\end{abstract}

Key Words: Slum area, slum level, settlement

\begin{abstract}
Abstrak : Kemunculan kawasan kumuh di perkotaan merupakan fenomena yang banyak terjadi di kota-kota besar di Indonesia, kondisi yang terjadi di Kampung-kampung kota saat ini tengah menghadapi berbagai permasalahan khususnya kualitas dan kuantitas di lingkungan permukiman yang terkait dengan kondisi sarana, prasarana, dan kondisi bangunan di kawasan tempat tinggal. Kampung Rawa Badung merupakan salah satu kawasan permukiman yang bukan hanya memiliki pertumbuhan penduduk yang terus meningkat dan kepadatan penduduk yang tinggi, tetapi juga memiliki kondisi sarana dan prasarana permukiman yang tidak memadai sehingga terindikasi merupakan kawasan kumuh karena dipengaruhi faktor lingkungan, terutama lingkungan tempat tinggal. Oleh karena itu, digunakan metode skoring pada penelitian ini dalam melakukan identifikasi kawasan permukiman kumuh, yang kemudian diklasifikasikan berdasarkan empat tingkat kekumuhan yaitu bukan kawasan kumuh, kawasan kumuh ringan, kawasan kumuh sedang dan kawasan kumuh berat. Dari tujuh indikator kekumuhan, Kampung Rawa Badung masuk pada kategori sedang dengan legalitas lahan legal, dan hasil analisis SWOT sebagai acuan solusi penanganan kawasan kumuh di Kampung Rawa Badung dan sebagai penentuan prioritas penanganan di kawasan permukiman.
\end{abstract}

Kata Kunci : Kawasan Kumuh, Tingkat kekumuhan, Permukiman

\section{PENDAHULUAN}

Kota sebagai pusat pelayanan dan kegiatan tidak terlepas dari adanya fenomena urbanisasi, yang menyebabkan jumlah penduduk di kota semakin tahun semakin bertambah. Kepadatan penduduk yang terus meningkat, kemudian memicu munculnya berbagai permasalahan kota, terutama terkait menurunnya daya dukung lingkungan perkotaan, jika kota padat penduduk seperti ini terus dibiarkan dan perkembangannya menjadi tidak terkendali, maka juga akan menimbulkan masalah permukiman yaitu tumbuhnya permukiman kumuh tak layak huni di daerah perkotaan yang dapat mengakibatkan menurunnya kualitas lingkungan permukiman dan menjadi kumuh (Krisandriyana, 2019).

Kawasan kumuh adalah kawasan di mana rumah dan kondisi hunian masyarakat di kawasan tersebut tidak sesuai dengan standar yang 
berlaku, baik standar kebutuhan, kepadatan bangunan, persyaratan rumah sehat, kebutuhan sarana air bersih, sanitasi maupun persyaratan kelengkapan prasarana jalan, ruang terbuka, serta kelengkapan fasilitas sosial lainnya (Kurniasih, 2007).

Kemunculan kawasan kumuh di perkotaan merupakan fenomena yang banyak terjadi di kota-kota besar di Indonesia, Kawasan permukiman kumuh secara nasional di Indonesia meluas dua kali lipat selama kurun waktu lima tahun terakhir (2014 -2018) seiring meningkatnya jumlah penduduk di perkotaan terutama Pulau Jawa (Direktorat Jenderal Cipta Karya Kementerian Pekerjaan Umum dan Perumahan Rakyat, 2016). Sehubungan dengan hal tersebut, kondisi yang terjadi di Kampung-kampung kota saat ini tengah menghadapi berbagai permasalahan khususnya kualitas dan kuantitas di lingkungan permukiman yang terkait dengan kondisi sarana, prasarana, dan kondisi bangunan di kawasan tempat tinggal

Kota Jakarta Timur merupakan salah satu wilayah yang terluas dan terdiri dari beberapa perkampungan, dari sisi demografis di DKI Jakarta. Jakarta Timur memiliki jumlah penduduk terbanyak dibandingkan dengan wilayah DKI Jakarta lainnya yaitu mencapai 2,84 juta jiwa dari keseluruhan jumlah penduduk yang terdapat di DKI Jakarta sebesar 10,17 juta jiwa (BPS Provinsi DKI Jakarta, 2018), dengan jumlah dan kepadatan penduduk yang tinggi di Kota Jakarta Timur menimbulkan berbagai dampak yang buruk, terutama masalah kepadatan penduduk di permukiman yang berdampak pada kualitas dan kuantitas lingkungan kawasan permukiman di Jakarta Timur. (BPS Jakarta Timur, 2019)

Kecamatan Cakung, Jakarta Timur merupakan salah satu kawasan permukiman yang bukan hanya memiliki pertumbuhan penduduk yang terus meningkat dan kepadatan penduduk yang tinggi, tetapi juga memiliki kondisi permukiman yang tidak sesuai standar sehingga terindikasi merupakan kawasan kumuh karena dipengaruhi faktor lingkungan, terutama lingkungan tempat tinggal (Dinas Perumahan Rakyat dan Kawasan Permukiman, 2019). Salah satu lokasi kawasan kumuh yang terdapat di Kecamatan Cakung adalah Kampung Rawa Badung yang memiliki luas sebesar 18,43 Ha.

Dalam menentukan identifikasi kawasan permukiman kumuh, dilakukan dengan mengidentifikasi kondisi sarana dan prasarana serta menentukan prioritas kriteria-kriteria yang berpengaruh terhadap kekumuhan menggunakan tujuh indikator permukiman kumuh. berdasarkan pengertian permukiman kumuh, serta standar pelayanan minimal yang dipersyaratkan secara nasional berdasarkan beberapa indikator yaitu: berdasarkan kementerian pekerjaan umum dan perumahan rakyat yaitu (Direktorat Jenderal Cipta Karya Kementerian Pekerjaan Umum dan Perumahan Rakyat, 2016)

\section{METODOLOGI}

Lokasi penelitian ini mengambil studi kasus di Kampung Rawa Badung, Kelurahan Jatinegara, Kecamatan Cakung, Jakarta TImur yang memiliki letak geografis 106049'35"' 106050'48' BT dan 06010'37' LS. Dengan batas wilayah utara Kecamatan Cilincing, batas wilayah Barat Kecamatan Pulo Gadung, batas wilayah selatan Kecamatan Duren Sawit dan batas timur Kecamatan Medan Satria. Kampung Rawa Badung yang memiliki Luas sebesar 18,43 Ha serta Danau sebesar $5 \mathrm{Ha}$

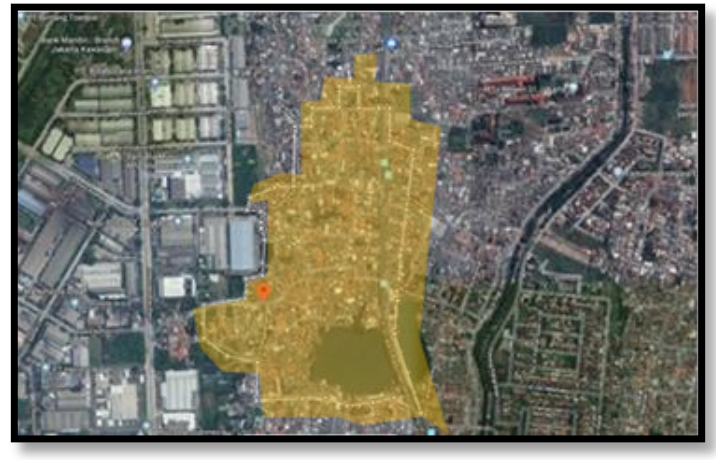

Gambar 1 Lokasi Penelitian

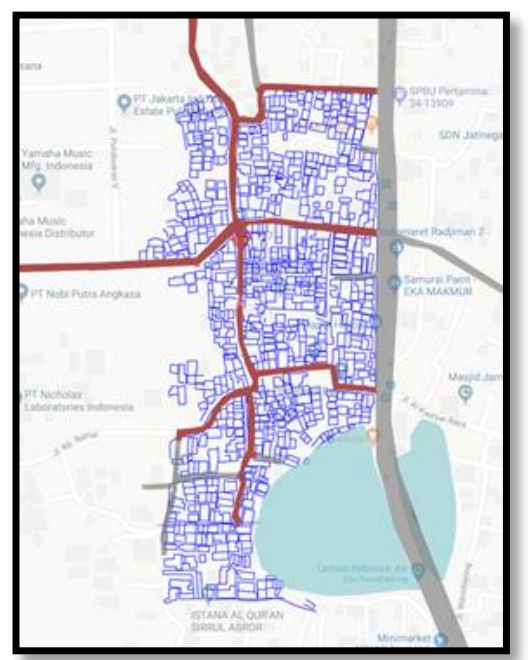

Gambar 2 Lokasi Penelitian Berdasarkan Kondisi Kepadatan Bangunan

Dilakukan survei dan wawancara dan mengisi form kuisioner mengenai program peningkatan kualitas permukiman dan kuisioner 
stakeholder mengenai lingkungan permukiman kumuh. Identifikasi Tingkat Kekumuhan dilakukan dengan memberikan skor pada kriteriakriteria berdasarkan skala penilaian yang mempengaruhi kawasan permukiman kumuh dari setiap indikator. Kemudian dilakukan analisis hingga menghasilkan klasifikasi tingkat kawasan kumuh di Kapung Rawa Badung. Berikut ini merupakan kriteria-kriteria pada setiap indikator kekumuhan yang dapat dilihat pada Tabel 1:

Tabel 1 Kriteria-Kriteria Indikator Kekumuhan

\begin{tabular}{|c|c|}
\hline ASPEK & KRITERIA \\
\hline \multirow[t]{4}{*}{$\begin{array}{l}\text { Kondisi bangunan } \\
\text { gedung }\end{array}$} & Ketidakteraturan Bangunan \\
\hline & Tingkat Kepadatan Bangunan \\
\hline & Ketidaksesuaian dengan \\
\hline & Persyaratan Teknis Bangunan \\
\hline Kondisi jalan & Cakupan Pelayanan Jalan \\
\hline \multirow[t]{3}{*}{ lingkungan } & Lingkungan \\
\hline & Kualitas Permukaan Jalan \\
\hline & Lingkungan \\
\hline \multirow{2}{*}{$\begin{array}{l}\text { Kondisi } \\
\text { penyediaan air } \\
\text { minum }\end{array}$} & $\begin{array}{l}\text { Ketidaktersediaan Akses Aman } \\
\text { Air Minum }\end{array}$ \\
\hline & $\begin{array}{l}\text { Ketidakterhubungan dengan } \\
\text { Sistem Drainase } \\
\text { Perkotaan }\end{array}$ \\
\hline \multirow[t]{7}{*}{$\begin{array}{l}\text { Kondisi drainase } \\
\text { lingkungan }\end{array}$} & $\begin{array}{l}\text { Ketidakmampuan mengalirkan } \\
\text { Limpasan Air }\end{array}$ \\
\hline & Ketidaktersediaan Drainase \\
\hline & Ketidakterhubungan dengan \\
\hline & Sistem Drainase \\
\hline & Perkotaan \\
\hline & Tidak Terpeliharanya Drainasee \\
\hline & Kualitas Konstruksi Drainase \\
\hline \multirow{3}{*}{$\begin{array}{l}\text { Kondisi } \\
\text { Pengelolaan Air } \\
\text { Limbah }\end{array}$} & Sistem Pengelolaan Air Limbah \\
\hline & Tidak Sesuai Standar Teknis \\
\hline & $\begin{array}{l}\text { Prasarana dan sarana } \\
\text { pengelolaan air limbah tidak } \\
\text { sesuai standar teknis }\end{array}$ \\
\hline \multirow[t]{3}{*}{$\begin{array}{l}\text { Kondisi } \\
\text { pengelolaan } \\
\text { persampahan }\end{array}$} & $\begin{array}{l}\text { Prasarana dan sarana } \\
\text { persampahan tidak sesuai } \\
\text { standar teknis }\end{array}$ \\
\hline & $\begin{array}{l}\text { Sistem pengelolaan } \\
\text { persampahan tidak sesuai } \\
\text { standar teknis }\end{array}$ \\
\hline & $\begin{array}{l}\text { Tidak terpeliharanya sarana dan } \\
\text { prasarana }\end{array}$ \\
\hline \multirow[t]{2}{*}{$\begin{array}{l}\text { Kondisi Proteksi } \\
\text { kebakaran }\end{array}$} & $\begin{array}{l}\text { Ketidaktersediaan prasarana } \\
\text { proteksi kebakaran }\end{array}$ \\
\hline & Ketidaktersediaan Sarana \\
\hline
\end{tabular}

\begin{tabular}{l}
\hline \multicolumn{1}{c}{ ASPEK } \\
\hline \multicolumn{1}{c}{ KRITERIA } \\
\hline $\begin{array}{l}\text { Sumber : Direktorat Pengembangan Kawasan Permukiman, } \\
2016\end{array}$
\end{tabular}

Dari subkriteria setiap indikator berdasarkan Direktorat Pengembangan Kawasan Permukiman, Tahun 2016 pada Tabel 1, langkah selanjutnya adalah sebagai berikut:

a. Pemberian skor setiap sub kriteria, berdasarkan parameter penilaian :

- Kualitas Baik (0\% - 25\%) : Skor 0

- Kualitas Cukup Baik (26\% - 50\%) : Skor 1

- Kualitas Buruk (51\% - 75\%) : Skor 3

- Kualitas Sangat Buruk 76\% - 100\%) : Skor 5

b. Perhitungan total penilaian setiap indikator didekati dengan menggunakan rumus sebagai berikut:

Keterangan :

$$
\mathrm{Si}=\Sigma B i \Sigma P
$$

$\mathrm{Si}=$ Total Skor pada Setiap Indikator, $\mathrm{Bi}=$ Skor

Sub Kriteria, P = Jumlah Sub Kriteria

\section{c. Klasifikasi Tingkat Kekumuhan}

Berikut merupakan rentang nilai tingkat klasifikasi yang didapatkan untuk setiap kelas yakni:

- Bukan Kawasan Kumuh : 0 - 18

- Kawasan Kumuh Ringan : 19 - 44

- Kawasan Kumuh Sedang : 45 - 70

- Kawasan Kumuh Berat : 71 - 95

Jenis metode penelitian kedua yang digunakan adalah penelitian evaluatif, Penelitian evaluatif merupakan suatu desain dan prosedur evaluasi dalam mengumpulkan dan menganalisis data mengenai permukiman kumuh dengan menggunakan SWOT, bagaimana kekuatan (strengths) mampu mengambil keuntungan (advantage) dari peluang (opportunities) yang ada, bagaimana cara mengatasi kelemahan (weaknesses) yang mencegah keuntungan (advantage) dari peluang (opportunities) yang ada. 


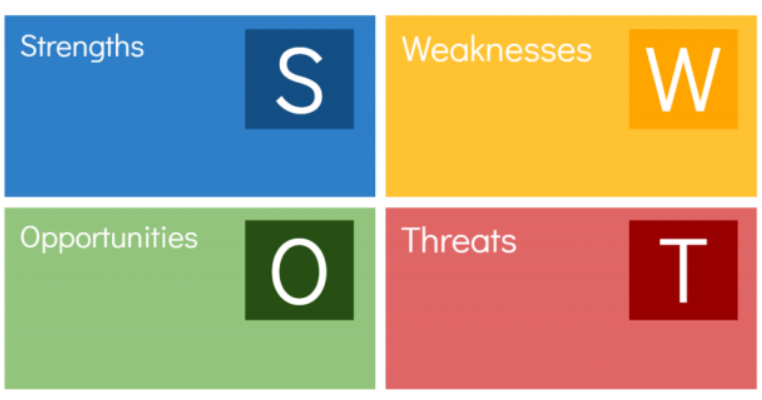

Gambar 3 Analisis SWOT

\section{HASIL DAN PEMBAHASAN}

Hasil dan pembahasan penelitian dapat dilihat dibawah ini sebagai berikut :

\section{a. Kondisi Sosial dan Demografi}

Jumlah penduduk Kota Jakarta Timur pada tahun 2016 adalah sebesar 2.868.8910 jiwa, jumlah penduduk tertinggi berada di Kecamatan Cakung sebesar 529.897 jiwa, dan kepadatan Penduduk untuk Kampung Rawa Badung juga mengalami peningkatan tiap tahunnya yang yang mayoritas bekerja di Buruh Kasar, Karyawan Industri, dan Pemulung Sumber Perekonomian warga Rawa Badung sebagian besar adalah sebagai buruh kasar, karyawan Pabrik, dan Pemulung. Karyawan Pabrik dan Pemulung menjadi sektor yang dominan untuk jenis mata pencaharian, hal ini dikarenakan wilayah Rawa Badung yang berdekatan dengan beberapa Pabrik besar, sementara berdasarkan tinjauan langsung ke lokasi penelitian, sektor pemulung juga menjadi sektor yang paling menonjol di wilayah rawa badung hal ini di karenakan adanya beberapa pasar seperti Pasar Pulo Jahe yang ada di RT06/13 dan Pasar Sebun yang berada di RT02/06. Lokasi yang berdekatan dengan Pasar serta banyaknya sampah pada wilayah ini menjadikan tempat hunian beberapa Kelompok pemulung. pedagang asongan atau makanan menempati posisi di $20 \%$ dari total jumlah penduduk di Kampung Rawa Badung.

\section{b. Tata Guna Lahan}

Berdasarkan hasil tinjauan lapangan , Kampung Rawa Badung dodominasi oleh guna lahan permukiman, dan guna lahan lain terdapat sarana pendidikan, perdagangan, ruang terbuka hijau dan danau/situ.

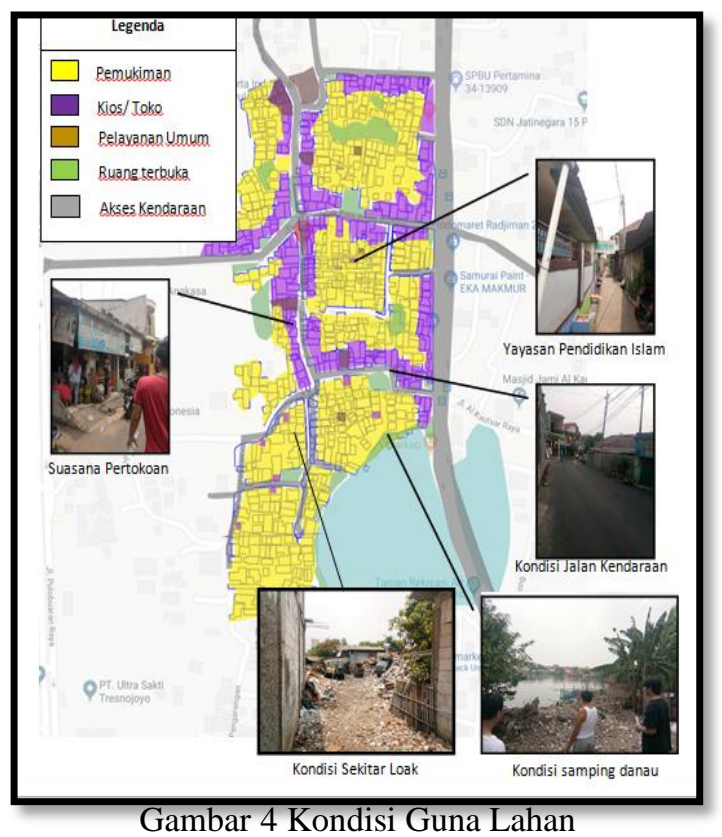

c. Kondisi Bangunan, Sarana, dan Prasarana Dari hasil survei yang sudah dilakukan bahwa bangunan di Kampung Rawa Badung didominasi oleh bangunan yang permanen karena dibangun dengan bahan material bata dan beton kolom praktis yang bukan material temporer, namun dengan lahan yang sempit kondisi tata masa bangunan di lokasi penelitian bahwa sebagian besar bangunan tempat tinggal tidak berdasarkan standard layak bangunan tempat tinggal dengan peraturan KDB $60 \%$, KDH $40 \%$, KLB dan GSB $50 \%$ (RDTR Kota Jakarta Timur, 2016)

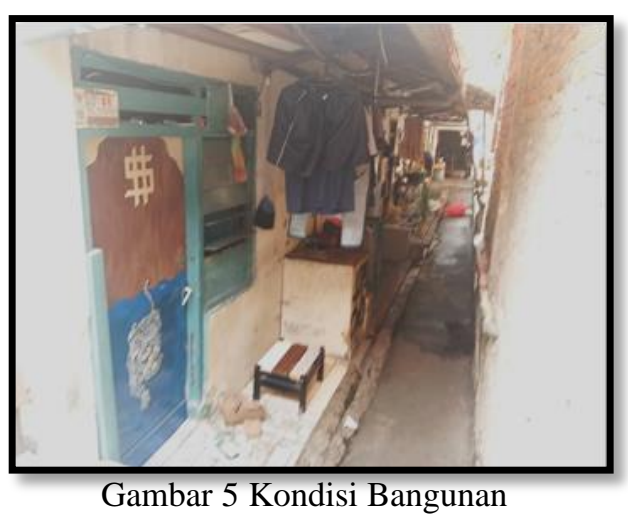

\section{Sarana dan Prasarana}

Kondisi jalan pemukiman di Kampung Rawa Badung cukup baik dengan menggunakan bahan material aspal dan lebar jalan sekitar 1 1,5 meter, kekurangannya yaitu jalan yang kecil tetapi kendaraan motor dapat masuk, akibatnya jalan menjadi macet dan tidak memiliki bahu jalan. 


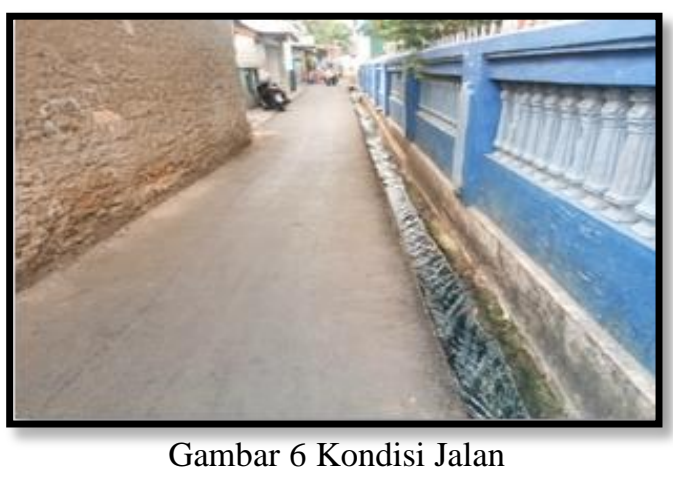

Berdasarkan hasil penelitian lapangan, kondisi pengelolaan sampah di Kampung Rawa Badung termasuk kondisi yang cukup baik, terdapat kegiatan rutin petugas sampah untuk mengumpulkan sampah dari masing - rumah warga ke TPS, pengumpulan sampah dan pengangkutan dilakukan pada malam hari dan pada pagi hari lokasi sudah bersih kembali diangkut petugas menggunakan mobil yang telah disediakan, sedangkan untuk kondisi drainase kurang baik, banyak sampah tersumbat dan menggenang tidak ada pengelolaan khusus terkait prasarana limbah dan draianse

Berdasarkan temuan lapangan, kondisi sarana di Kampung Rawa Badung masih belum memadai dengan kondisi kurang tertata dengan baik. terdapat sarana pertokoan dan kios, pasar tradisional, bangunan sekolah SD, SMP, SMA, masjid, balai pengobatan umum dan klinik kebidanan.

\section{d. Analisis Tingkat Kekumuhan}

Hasil skoring dari setiap indikator berdasarkan hasil penilaian dari sub kriteria untuk mengetahui tingkat kualitas yang digunakan analisis untuk penanganan permukiman kumuh dapat dilihat pada Tabel 2. Dari hasil Tabel 2 dapat dilihat untuk tingkat kualitas setiap indikator kekumuhan di lokasi Kampung Rawa Badung, semakin besar hasil skor yang didapatkan maka semakin buruk kualitas yang ada dan sebaliknya semakin kecil skor yang didapatkan maka kualitas semakin baik. Dari hasil skor tersebut juga dapat diketahui permasalahan penyebab kekumuhan dari setiap lokasi.
Tabel 2 Skoring Kriteria Indikator Kekumuhan

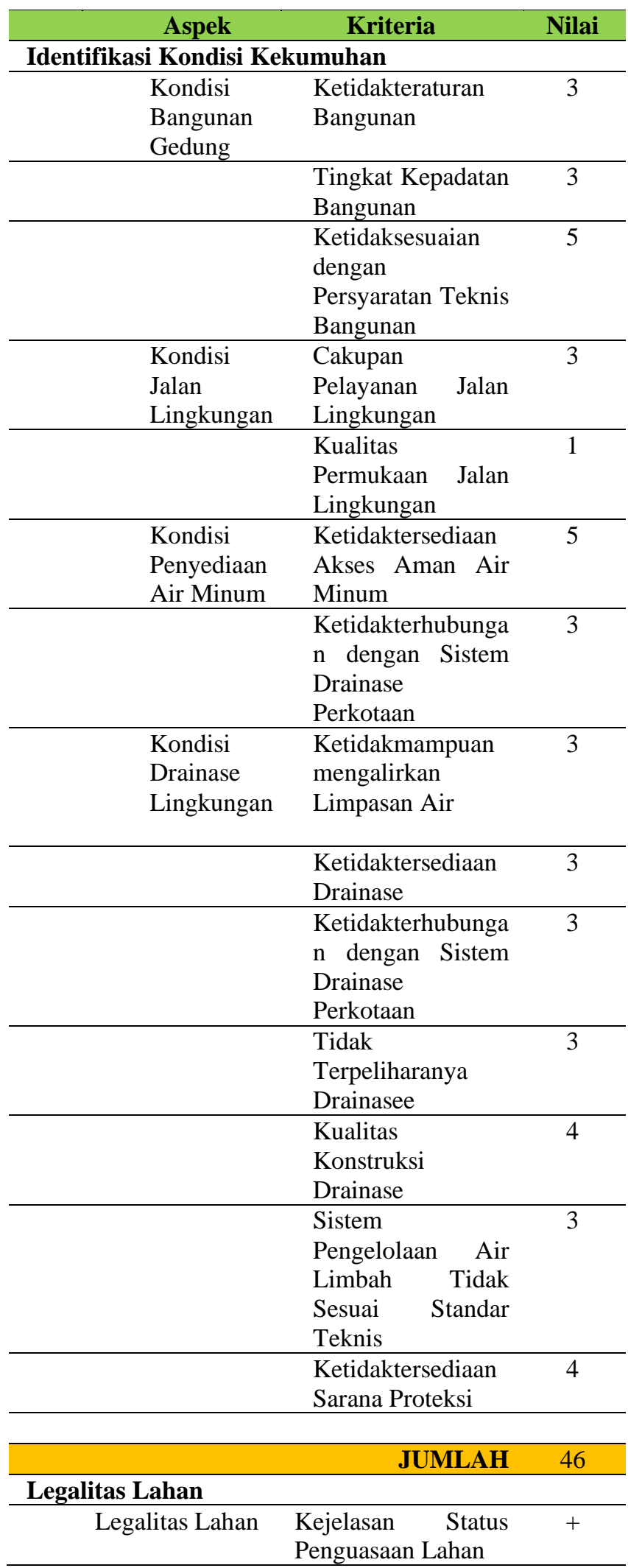

Sumber : Hasil Analisis, 2019 
Berdasarkan hasil analisis skoring kriteria indikator kekumuhan di lokasi Kampung Rawa Badung, total nilai keseluruhan aspek kekumuhan adalah sebesar 46 identifikasi kondisi kekumuhan, dengan kondisi yang sangat buruk (nilai 5) adalah kondisi teknis bangunan dan penyediaan air minum, sedangkan nilai buruk untuk kondisi kualitas konstruksi drainase. Legalitas lahan Kampung Rawa Badung berada di guna lahan legal atau sesuai dengan aturan Rencana Tata Ruang Wilayah Jakarta Timur karena berada di zona perumahan dan permukiman.

Berdasarkan total nilai keseluruhan skoring kriteria indikator kekumuhan, berjumlah sebesar 46, yang masuk pada tingkat kekumuhan sedang. Dalam perencanaan pola penanganan kawasan kumuh dan tipologi kawasan kumuh yang ditetapkan Direktorat Pengembangan Kawasan Pemukiman, pola penanganan kekumuhan sedang dengan status legal, adalah dengan peremajaan Bangunan Gedung, Penyediaan Air Minum, Drainase Lingkungan, Air Limbah, Proteksi Kebakaran.

\section{e. Analisis SWOT}

\section{Analisis Strength (Kekuatan/Potensi)}

- Terdapat sarana permukiman yang cukup lengkap

- Kondisi prasarana persampahan cukup baik, terdapat pengelolaan sampah yang rutin dilakukan oleh petugas ampah setiap hari

- Terdapat situ/danau di lokasi penelitian yang juga dapat djadikan sebagai sebagai area lahan terbuka warga untuk menjadi tempat berkumpul dan bersantai, banyak warga memancing ikan di Situ Rawa Badung

- Kondisi material jalan sebagian besar sudah cukup baik yaitu dengan bahan aspal

\section{Analisis Weakness (Kelemahan)}

- Kondisi jalan utama dengan rata - rata lebar 4 - $5 \mathrm{~m}$, sudah di aspal, namun pada saat hujan turun, terdapat genangan - genangan air, dikarenakan aliran saluran Drainase yang kurang maksimal

- Untuk pengolahan sampah di kampung rawa badung ini, sudah tergolong baik, sampah di ambil oleh petugas sampah pada pagi hari dan sore hari. Namun masih ada beberapa rumah yang masih kurang memperhatikan kebersihan lingkungan. masih terdapat warga yang membuang sampah di sembarang tempat dan membuang di dekat area sekitar danau dan saluran drainase

- Tidak adanya titik air (hydrant) pada kawasan permukiman kampung ini dapat menyulitkan dan memperlambat penanggulangan bencana kebakaran yang terjadi.

- Kebiasaan warga Kampung Rawa Badung membuang sampah rumah tangga di sekitar Situ Rawa Badung, sehingga mencemari udara dan lingkungan sekitar

\section{Analisis Opportunities (Peluang)}

- Terdapat Sarana perdagangan yang cukup lengkap salah satunya yaitu pasar yang dekat dengan lokasi kampung Rawa Badung dapat menjadi peluang warga untuk mendapatkan mata pencaharian

- Terdapat Ruang terbuka hijau yang berada di kampung Rawa Badung ini adalah situ rawa badung. yang menjadi tempat berkumpul warga untuk bersantai dan memancing ikan merupakan peluang untuk pengembangan area wisata dan menjadi daya tarik di kampung tersebut

\section{Analisis Threats (Ancaman)}

Kondisi pemukiman padat penduduk di kampung Rawa Badung dkhawatirkan mudah terjadi kebakaran dan merembet bangunan-bangunan lain disekitarnya, keadaan rumah yang berderet dan cukup padat memungkinkan api dapat mudah menyebar kebagian terdekat jika terjadi kebakaran dan akses pemadam kebakaran untuk masuk ke dalam sangat terbatas, akses jalan 4-5 $\mathrm{m}$ tidak mencapai ke semua rumah penduduk

Dari poin-poin diatas, adapun beberapa strategi yang digunakan dalam analisis SWOT yaitu:

1. Strategi S-O adalah strategi yang digunakan Strength (kekuatan) untuk memanfaatkan Opportunity (peluang). Dimana dalam poin diatas yang dihasilkan kekuatan yang memanfaatkan peluang adalah program pemerintah untuk menyediakan kelengkapan sarana dan prasarana penunjang permukiman di kampung Rawa Badung dan rencana hunian vertikal untuk memenuhi kapasitas daya tampung lahan permukiman,

2. Strategi W-O adalah strategi untuk Mengatasi Weakness (kelemahan) dengan memanfaatkan Opportunity (peluang). Pada poin diatas yang dihasilkan kelemahan yang memanfaatkan peluang adalah program pemerintah yang bukan 
hanya fisik saja tetapi sosial dan ekonomi, seperti pengembangan danau di Kampung Rawa Badung sebagai objek wisata yang ikut meningkatkan nilai ekonomi warga sekitar Kampung Rawa Badung

3. Strategi S-T adalah strategi yang digunakan Strength (kekuatan) untuk menghindari Threats (ancaman) yaitu Kepadatan bangunan yang rendah dapat mencegah terjadinya bencana kebakaran

4. Strategi W-T adalah strategi yang Meminimalkan Weakness (kelemahan) dan menghindari Threats (ancaman) adalah Perbaikan utilitas pada kawasan kumuh serta kebijakan dan kelembagaan yang lebih baik lagi oleh pemerintah dalam menata kawasan permukiman khususnya di Kampung Rawa Badung

\section{PENUTUP}

\section{Simpulan}

Berdasarkan hasil analisis tingkat kekumuhan di dapatkan beberapa kesimpulan sebagai berikut:

a. Total nilai keseluruhan aspek kekumuhan di Kampung Rawa Badung adalah sebesar 46 dengan kondisi yang sangat buruk (nilai 5) adalah kondisi teknis bangunan dan penyediaan air minum, sedangkan nilai buruk untuk kondisi kualitas konstruksi drainase.

b. Legalitas lahan Kampung Rawa Badung berada di guna lahan legal atau sesuai dengan aturan Rencana Tata Ruang Wilayah Jakarta Timur karena berada di zona perumahan dan permukiman.

c. Nilai keseluruhan skoring kriteria indikator kekumuhan, berjumlah sebesar 46, yang masuk pada tingkat kekumuhan sedang.

d. Berdasarkan perencanaan pola penanganan kawasan kumuh dan tipologi kawasan kumuh yang ditetapkan Direktorat Pengembangan Kawasan Pemukiman, pola penanganan kekumuhan sedang dengan status legal, adalah dengan peremajaan Bangunan Gedung, Penyediaan Air Minum, Drainase Lingkungan, Air Limbah, Proteksi Kebakaran.

e. Meskipun pengelolaan persampahan di lokasi penelitian sudah cukup baik, namun terdapat beberapa warga Kampung Rawa Badung yang membuah sampah dan limbahnya ke danau dan beberapa titik saluran drainase, sehingga diperlukan pengawasan dan pembinaan kembali oleh pemerintah setempat

\section{Saran}

Melakukan lebih banyak survei dan wawancara ke beberapa stakeholder seperti: pihak Dinas Cipta Karya bagian Perumahan dan Permukiman Kumuh

\section{DAFTAR PUSTAKA}

Badan Pusat Statistik. Jumlah Penduduk dan Rasio Jenis Kelamin Menurut Kabupaten Kota di Provinsi DKI Jakarta 2018. Jakarta Pusat : Badan Pusat Statistik

Badan Pusat Statistik, 2019. Jakarta Timur Dalam Angka 2019. Jakarta Timur : Badan Pusat Statistik

Direktorat Pengembangan Kawasan Pemukiman, 2016. Panduan Pendampingan Penyusunan Raperda tentang Pencegahan dan Peningkatan Kualitas Perumahan Kumuh dan Permukiman Kumuh. Jakarta: Direktorat Jenderal Cipta Karya Kementerian Pekerjaan Umum dan Perumahan Rakyat.

Fitria, Niken, 2014. Identifikasi Karakteristik Lingkungan Permukiman Kumuh di Kelurahan Kapuk, Jakarta Barat, Jurnal Teknik Pomits Vol. 3, No. 2

Istikasari, M., \& Khadiyanto, 2014. Identifikasi Permukiman Kumuh di Pusat Kota Jambi, Jurnal Ruang Vol. 2, No. 4

Kurniasih, Sri, 2007. Usaha Perbaikan Permukiman Kumuh di Petukangan Utara-Jakarta Selatan, Jurnal Teknik Arsitektur Vol 1, No. 3

Krisandriyana, Maresty, 2019. Faktor Yang Mempengaruhi Keberadaan Kawasan Permukiman Kumuh Di Surakarta. Jurnal Desa-Kota Vol. 1, No.1

Rencana Tata Ruang Wilayah (RTRW DKI Jakarta Tahun $2011-2030$

Ruli, As'ari, 2014. Penataan Permukiman Kumuh Berbasis Lingkungan. Jurnal Geografi Vol. 15 No.1

Standar Nasional Indonesia (SNI) Nomor 031733-2004. Tata Cara Perencanaan Lingkungan Perumahan di Perkotaan. Jakarta:Badan Standarisasi Nasional.

Sumarwanto, 2014. Pengaruh Masyarakat Berpenghasilan Rendah Dan Permukiman Kumuh Terhadap Tata Ruang Wilayah Di Semarang, Jurnal Ilmiah UNTAG Semarang Vol. 3, No. 1

Wihadanto, Ake, 2017. Analisis Karakteristik dan Penilaian Tingkat Kekumuhan Kawasan Permukiman 'Kampung Braga' - Kota 
Bandung. Jurnal Pembangunan Wilayah dan Perdesaan Vol. 1, No. 2

Zulkarnaini, Wilko, 2019. Faktor-Faktor Yang Mempengaruhi Permukiman Kumuh Di Kota Bukittinggi. Jurnal PLanologi Vol.16, No.2 